Jurnal Akuntansi dan Keuangan (JAK)

Volume 6, No. 2 Oktober Tahun 2021

Page: 37 - 49

http://ojs.uho.ac.id/index.php/jak-uho/issue/archive

e-ISSN: 2088-4656

\title{
ANALISIS IMPLEMENTASI ENTERPRISE RESOURCES PLANNING DALAM MENINGKATKAN KINERJA SATUAN PENGAWASAN INTERN PTPN XIV PERSERO UNIT KEBUN ASERA
}

\author{
Ishak Awaluddin $^{1}$, Erwin Hadisantoso ${ }^{2}$, Saldi Al Ayyubi ${ }^{3}$ \\ Jurusan Akuntansi Fakultas Ekonomi dan Bisnis Universitas Halu Oleo Kendari \\ Sulawesi Tenggara
}

\begin{abstract}
ABSTRAK
Penelitian ini bertujuan untuk mengetahui dan menjelaskan implementasi sistem ERP dalam meningkatkan kinerja Satuan pengawasan internal PT Perkebunan XIV. Metode pengumulan data menggunakan wawancara, observasi dan dokumentasi. Penelitian ini termasuk dalam penelitian kualitatif yang menggunakan metode analisis deskriptif. Berdasarkan hasil penelitian Mengenai implementasi Enterprise Resource Planning dalam meningkatkan kinerja auditor internal dapat di simpulkan bahwa implementasi Enterprise Resource Planning tidak memberikan dampak yang sangat fositif dalam menigkatkan kinerja satuan pengwasan internal baik dari segi melaksanakan tugas dan fungsinya, pemeriksaan audit akan tetapi memiliki dampak yang cukup baik bagi kinerja perusahaan yang di karenakan informasi entitas di dapatkan lebih cepat sehingga proses monitoring dapat di lakukan dengan efektif. Kurang baiknya dampak yang di berikan oleh Enterprise Resource Planning sebabkan oleh kurangnya pemahaman auditor internal dalam menggunakan sistem Enterprise Resource Planning di lingkup satuan kerja pengawasan internal PT perkebunan XIV serta data yang di hasilkan oleh ERP SAP belum terinci.

Kata kunci : Pengawasan Internal, Sistem Informasi, Enterprise resource planning.
\end{abstract}

\begin{abstract}
The purpose of This study aims to identify and explain the implementation of the ERP system in improving the performance of the internal control unit of PT Perkebunan XIV. Methods of collecting data using interviews, observation and documentation. This research is included in qualitative research using descriptive analysis method. research results Regarding the implementation of Enterprise Resource Planning in improving the performance of internal auditors, it can be concluded that the implementation of Enterprise Resource Planning does not have a very positive impact in improving the performance of the internal control unit both in terms of carrying out tasks and functions, audit examinations will have a fairly good impact on performance. This is done because entity information is obtained faster so that the monitoring process can be carried out effectively. The lack of impact provided by Enterprise Resource Planning is due to the lack of understanding of the internal auditors in the Enterprise Resource Planning system in the scope of work of PT plantation XIV's internal control and the data generated by ERP SAP has not been detailed.
\end{abstract}

Keywords: Internal Control, Information System,

Enterprise resource planning. 
Jurnal Akuntansi dan Keuangan (JAK)

Volume 6, No. 2 Oktober Tahun 2021

Page: 37 - 49

http://ojs.uho.ac.id/index.php/jak-uho/issue/archive

e-ISSN: 2088-4656

\section{PENDAHULUAN}

Sistem pengendalian internal (SPI) merupakan suatu perencanaan yang meliputi struktur organisasi, semua metode dan alat-alat yang dikordinasikan di dalam perusahaan untuk memeriksa ketelitian dan kebenaran data akuntansi, mendorong efisiensi, dan membantu mendorong dipatuhi kebijakan manajemen yang telah ditetapkan. Kewajiban menerapkan prinsip-prinsip pengendalian. Ada beberapa penyebab krisis perekonomian yang terjadi di Asia yaitu Dewan Komisaris dan Dewan Direktur yang tidak efektif, adanya kebocoran dalam pengendalian internal perusahaan, tidak menyajikan pengungkapan yang memadai dalam laporan keuangan perusahaan, laporan keuangan perusahaan disajikan secara tidak wajar dan kurang patuhnya terhadap kebijakan organisasi (Asian Development Bank ADB). Oleh karena itu di butuhkannya sistem pengawasan dan informasi yang tepat dalam mengatasi masalah yang dapat terjadi terhadap sistem pengendalian internal. Sebuah sistem informasi harus di tangani dengan tepat dan akurat agar perusahaan atau badan dapat meminimalisir terjadinya fraud dan kesalahan baik di sengaja maupun tidak di sengaja. Dengan perkembangan teknologi yang semakin pesat, saat ini banyak perusahaan yang menerapkan teknologi informasi dalam kegiatan operasi perusahaan. Office of the New York State Comptroller (2010:1) mengeluarkan sebuah panduan berjudul The Practice of Internal Controls, dokumen ini menjelaskan pengendalian dalam sektor teknologi informasi dimana teknologi informasi cenderung mempengaruhi keseluruhan atau banyak aspek dalam tata kelola operasi keuangan dan seharusnya tidak dipisahkan dan dibedakan dari pengendalian internal.

Sebelum penerapan Enterprise Resource Planning di lakukan pada PT Perkebunan $\mathrm{XIV}$, informasi yang di peroleh atas keadaan unit usaha masih sangat terbatas dan masih kurang sesuai dengan standar governance tekhnologi informasi (IT) di perusahan yang menekankan pada peningkatan kualitas dan kuantitas serta ketepatan waktu dalam memberikan informasi-informasi yang di butuhkan oleh perusahaan (entitas). dengan kurangnya kualitas dan keterlambatan waktu dalam mengelolah informasi-informasi perusahaan dapat menyebabkan kurang efektifnya sistem pengendalian intern di perusahaan, oleh karena itu di butuhkan sistem yang dapat memberikan nilai tambah dalam pengelolahan perusahaan serta membantu auditor internal dalam melakukan pemeriksaan pada bagian keuangan dan monitoring perusahaan serta mendukung atas tercapainya Good Corporate governance. Penelitian ini bertujuan untuk mengetahui bagaimana penerapan enterprise resource planning dalam mengkatkan kinerja satuan pengawasan internal di PT Perkenbunan Nusantara XIV.

\section{Sistem Informasi}

\section{LANDASAN TEORI}

Sistem informasi merupakan sistem yang ada di dalam suatu organisasi dimana kebutuhan pengolah transaksi harian yang mendukung fungsi operasi organisasi yang manajerial dengan kegiatan strategi dari suatu organisasi dengan tujuan dapat menyediakan kepada pihak luar tertentu dengan laporan-laporan yang diperlukan (Sutabri, 2012). 
Jurnal Akuntansi dan Keuangan (JAK)

Volume 6, No. 2 Oktober Tahun 2021

Page: 37 - 49

http://ojs.uho.ac.id/index.php/jak-uho/issue/archive

e-ISSN: 2088-4656

2. Sistem Informasi Akuntansi

Sistem Informasi Akuntansi (SIA) adalah organisasi formulir, catatan, dan laporan yang didesain untuk menyediakan informasi keuangan bagi pengelola kegiatan usaha, memperbaiki informasi yang dihasilkan oleh sistem yang sudah ada sebelumnya, memperbaiki pengendalian akuntansi dan juga pengecekan internal serta membantu memperbaiki biaya klerikal (biaya tulis menulis) dalam pemeliharaan catatan akuntansi, (Mulyadi: 2008).

3. Enterprise Resources Planning (ERP)

Sistem ERP merupakan sebuah sistem yang mampu mengintegrasikan keseluruhan sistem-sistem dan proses bisnis yang ada di suatu organisasi atau perusahaan maupun yang berkaitan dengan lingkungan luar organisasi. Dengan adanya ERP, maka keseluruhan proses-proses yang ada di perusahaan akan saling terhubung dan bisa diotomatisasikan. Tujuan dari adanya ERP adalah sebagai penyedia aliran informasi antar keseluruhan fungsi di dalam organisasi dan juga mengelola hubungan dengan pihak luar organisasi Lebih lanjut menurut (Bidgoli 2004: 707).

4. Konsep Dasar ERP

Pada hakekatnya konsep dasar ERP dapat diterjemahkan sebagai berikut:

1. ERP terdiri atas paket software komersial yang menjamin integrasi yang mulus atas semua aliran informasi di perusahaan, yang meliputi keuangan, akuntansi, sumber daya manusia, rantai pasok dan informasi konsumen.

2. Sistem ERP adalah paket sistem informasi yang dapat dikonfigurasi, yang mengintegrasikan informasi dan proses yang berbasis informasi di dalam dan melintas area fungsional dalam sebuah organisasi.

3. ERP merupakan satu basis data, satu aplikasi dan satu kesatuan antarmuka (interface) di seluruh enterprise.

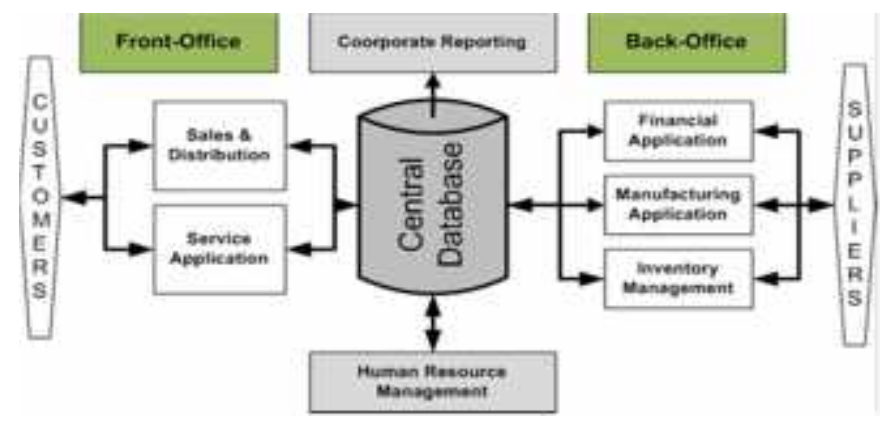

Gamba 2.1: Konsep Dasar ERP

(Sumber) https://jeannerroselia.wordpress.com/2013/07/18konsep-dasar-erp/.diakses 5 september 2020)

5. Kinerja

"Performance is defined as the record of outcomes produced on a specified job function or activity during time period. Prestasi atau kinerja adalah catatan tentang hasil- 
Jurnal Akuntansi dan Keuangan (JAK)

Volume 6, No. 2 Oktober Tahun 2021

Page: 37 - 49

http://ojs.uho.ac.id/index.php/jak-uho/issue/archive

e-ISSN: 2088-4656

hasilyang diperoleh dari fungsi- fungsi pekerjaan tertentu atau kegiatan selama kurun waktu tertentu (Ruky, 2002).

6. Sistem Pengawasan Internal.

Pengawasan internal adalah suatu peroses yang di laksanakan oleh dewan direksi, manajemendan personel lainya dalam suatu entitas, yang di rancang untuk menyediakan keyakinan yang memadai berkenan dengan pencapaian tujuan (Boynton dkk, 2003:373).

\section{METODE PENELITIAN}

Objek penelitian ini adalah analisis Implementasi Enterprise Resource Planning (ERP) terhadap Kinerja Satuan Pengawasan Internal pada PTPN XIV (Persero). Penelitian ini di lakukan di PTPN XIV (persero) kantor SPI, jln. Urip Sumohardjo No.72-76 Makassar, dan Kantor Unit Kebun Asera, Desa Wawontoaho, Kecematan Wiwirano, Kabupaten Konawe Utara, Sulawesi Tenggara. Jenis data yang di gunakan dalam penelitian ini yaitu data kualitatif data kualitatif dalam penlitian ini yaitu berupa data berupa struktur organisasi, hasil wawancara kepada pihak perusahan terkait penerapan enterprise resource palanning.

Jenis data dalam penelitian ini adalah data primer dan sekunder. Data primer di peroleh penliti dari wawancara, observasi dan dokumentasi secara langsung terkait penerapan Enterprise Resource Planning, sedangkan data sekunder dallam penelitian ini adalah datadata yang di dapatkan peneliti melalui media, website dan lain-lain terkait penelitian ini.

Metode pengumpulan data yang di gunakan dalam penelitian ini adalah Wawancara, observasi dan dokumentasi. Wawancara digunakan sebagai teknik pengumpulan data apabila peneliti ingin melakukan studi pendahuluan untuk menemukan permasalahan yang harus diteliti, dan juga apabila peneliti ingin mengetahui hal-hal dari responden yang lebih mendalam dan jumlah respondennya sedikit/kecil. Teknik pengumpulan data ini mendasarkan diri pada laporan tentang diri sendiri atau self-report, atau setidak-tidaknya pada pengetahuan dan atau keyakinan pribadi (Sugiyono 2017: 138) Adapun yang menjadi informan dalam penelitian ini adalah anggota Satuan Pengawasan Internal PTPN XIV (persero) dan User Enterpricse resouce planning unit PKS Asera, Observasi sebagai teknik pengumpulan data yang mempunyai ciri spesifik bila di bandingkan dengan teknik yang lainnya. Observasi di lakukan dengan menlihat langsung di lapangan misalnya kondisi lingkungan kerja dan ruang kerja yang dapat di gunakanuntuk menentukanfaktor layak yang di dukung dengan adanya wawancara dan kuisioner. (Sugiyono 2017: 203). Pada penelitian ini, peneliti akan melakukan observasi terhadap sistem yang digunakan oleh PT Perkebunan XIV. Dokumentasi merupakan catatan peristiwa yang telah berlalu. Dokumentasi dapat berupa tulisan, gambar, dan karya-karya monomental dari seseorang. Hasil dari wawancara akan lebih kredibel apabila di dukung dokumen-dokumen, dan menambah informasi untuk penelitian.

Analisis yang di gunakan pada penelitian ini analisis data kualitatif deskriptif, analisis data kualitatif yaitu mengenai fokusmasalah yang di tetapkan secara rinci untuk dicari cara pemecahannya masalahnya dengan memberikan solusi atau rekomendasi terkait sistem informasi yang meliputi: tekhnologi informasi, sistem informasi, pemgumpulan data, 
Jurnal Akuntansi dan Keuangan (JAK)

Volume 6, No. 2 Oktober Tahun 2021

Page: 37 - 49

http://ojs.uho.ac.id/index.php/jak-uho/issue/archive

e-ISSN: 2088-4656

penyimpanan, pemeliharaan, keamanan, organisasi dan pengambilan kembali. Adapun tahapan dalam melakukan analisis data adalah, (Mengumpulkan data terkait penerapan sistem enterprice resourxe planning SAP R/3, dan SPI yang berada di lingkup PTPerkebunan XIV baik melalui wawancara, observasi maupun dokumentasi, Reduksi data tekhnik analisis ini di gunakan untuk penyerderhanaan, penggolongan, dan membuang yang tidak perlu data sedemikian rupa zsehingga informasi tersebut menghasilkan informasi yang bermakna dan memudahkan dalam penarikan kesimpulan, Menyajikan data atas hasil yang telah di peroleh dari informasi-informasi yang di dapatkan dan di susun secara sistematis dan mudah di pahami, Menarik kesimpulan, saran dan rekomendasi terhadap penerapan sistem Enterprice Resourse Planning dalam meningkatkan kinerja SPI).

\section{Hasil Penelitian}

\section{HASIL DAN PEMBAHASAN}

1. Analisis Sistem yang Telah Di Terapkan Oleh PTPN XIV Unit Kebun Asera

Berdasarkan hasil penelitian yang telah di lakukan oleh peneliti kepada User ERP Unit Kebun asera terdapat beberapa kelemahan yang sering terjadi pada sistem yang selama ini di terpkan oleh PT Perkebuan XIV. Kelemahan-kelemahan tersebut antara lain:

1) Sering terjadi eror yang di sebabkan oleh Network yang menyebabkan hilangnya koneksi atas server ERP. Hal ini di akibatkan karena jangkauan atas jaringan masih kurang stabil.

2) Komputer/Laptop yang di gunakan kadang mengalami eror atau macet sehingga dapat menghambat karyawan dalam menginput data. Hal ini di karenakan tidak adanya sarana prasarana yang di sediakan oleh pihak perusahaan berupa fasilitaas komputer yang mendukung.

3) Kurangnya komunikasi yang terjalin antara karyawan yang menyebabkan sering terjadi keterlambatan dalam menginput data.

4) Perbaikan atas kerusakan alat/fasilitas kantor membutuhkan waktu yang cukup lama sehingga menghambat pekerjaan dari setiap user/pengguna.

Untuk itu peneliti memberi usulan pemecahan masalah dari beberapa kelemaha dari sistem ERP (enterprise resource planning) yang sedang berjalan saat ini, dengan cara sebagai berikut:

1. Memasang koneksi jaringan (Connection Network) yang lebih stabil sehingga tidak memperlambat dalam melakukan proses data (Data Processing).

2. Menambah Reaptear untuk memperkuat jaringan di lingkup kantor Unit asera jadi apa bila terjadinya eror pada jaringan wifi kantor dapat di atasi dengan jaringan internet seluler

3. Sebaikanya pihak perusahaan/kantor menganggarkan fasilitas berupa kumputer untuk meningkatkan kinerja userdalam menjalakan program/sistem ERP.

4. Pemberian, pengenalan, pelatihan dan pengarahan kepada setiap karyawan akan pentingnya komunikasi antara sesama karyawan demi meminimalisir keterlambatan data, kesalahan penginputan data dan mengesampingkan ego masing-masing karyawan.

5. Selalu cepat tanggap dalam mengatasi kerusakan tekhnis yang di alami oleh user ERP, serta rutin melakukan perawatan (Maintance) terhadap fasilitas-fasilitas yang tersedia, baik itu milikk pribadi maupun milik kantor. 
Jurnal Akuntansi dan Keuangan (JAK)

Volume 6, No. 2 Oktober Tahun 2021

Page: 37 - 49

http://ojs.uho.ac.id/index.php/jak-uho/issue/archive

e-ISSN: 2088-4656

\section{Kelemahan Sistem}

(Enterprise Resource Planning). Hal yang menjadi masalah paling vital adalah saat sistem tersebut mengalami error data. data disini yang dimaksud adalah sistem tidak bisa diakses atapun untuk menginput data. Masalah seperti ini timbul karena tempat penyimpanan data mengalami gangguan ataupun bisa overload data. Untuk mengatasi masalah tersebut pihak admin harus menghapus data-data yang sudah tidak terpakai atau dibackup data ke media penyimpanan lain. Terkait masalah ini seharusnya perusahaan tidak hanya memakai satu server sebagai media penyimpanan data, dan harus membuat server baru sebagai cadangan apabila server yang satu mengalami overload data. Jaringan internet sangat penting dalam sistem ini untuk melakukan input data, karena sistem ERP (Enterprise Resource Planning) ini penginputan data dilakukan secara online. Dalam hal ini, perusahaan memiliki masalah pada jaringan internet di karenakan lokasi perusahaan masih memiliki kondisi jaringan yang masih buruk. Karena sistem ERP (Enterprise Resource Planning) ini terdiri dari peramalan, perencanaan dan penjadwalan, jadi data harus dapat di input secara cepat dan akurat. Untuk mengatasi masalah tersebut pihak perusahaan seharusnya menambah atau memperbarui jaringan serta menabah sebuah reapter untuk memperkuat jaringan komunikasi di lingkup perusahaan. Untuk itu karyawan dapat menginput data tanpa khawatir akan terjadinya eror pada data yang akan di input tetapi dalam mengatasi masalah yang terjadi pada user yag mengalami kesalahan jaringan, PT Perkebunan XIV memberikan konpensai atas keterlambatan penginputan dengan syarat user wajib melaporkannya kepada Kantor Direksi PT Perkebunan XIV bahwa input tidak bisa di lakukan karena adanya masalah koneksi atau jaringan. Perawatan suatu sistem informasi memang tidak mudah dan murah. Apalagi jika sistem tersebut merupakan buatan perusahaan lain, sehingga mengeluarkan biaya untuk maintenance. Selain dari segi perawatan sistem, sisi karyawan juga menjadi sorotan. Hal ini terkait masalah kualitas yang dihasilkan dari sistem tersebut. Prosedur Penerapan ERP SAP

Dalam mekanisme penerapan ERP SAP R/3 proses dari pengoperasian sistem terbagi atas dua tahapan yaitu tahap awal (start) dan tahap penyelesaian (End) untuk lebih jelasnya dapat dilihat pada gambar flowchart checkroll di bawah ini:

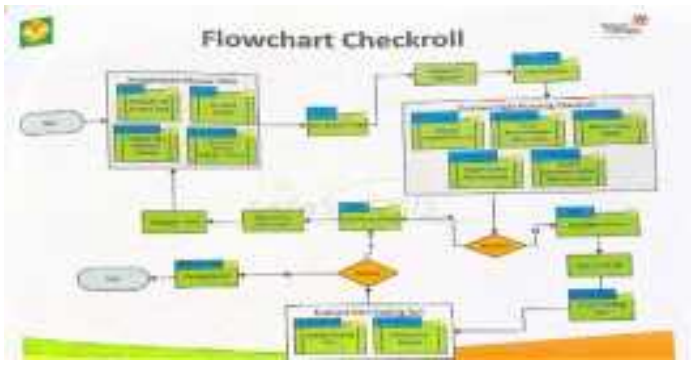

Gambar 1 Flowchart checkroll

3. Penggunaan ERP Pada PT Perkebunan XIV

Berdasarkan hasil observasi yang dilakukan terhadap penerapan ERP di Unit Kebun Asera perusahaan menggunakan beberapa modul SAP R/3, bagian-bagian tersebut terdiri dari 6 bagian yaitu:

1) Keuangan dan Akuntansi Financial and Accouinting (FI)

Berdasarkan wawancara yang saya lakukkan kepada Jakwan S.H pada bagian financial mengenai implementasi erp di bagian keuangan, mengatakan bahwa sebenarnya 
Jurnal Akuntansi dan Keuangan (JAK)

Volume 6, No. 2 Oktober Tahun 2021

Page: 37 - 49

http://ojs.uho.ac.id/index.php/jak-uho/issue/archive

e-ISSN: 2088-4656

"Kalau masalah kesulitan atas jaringan dan fasilitas yang tersedia memang sangat berdampak pada pekerjaan yang dia lakukan pada intinya kesulitannya pada hal ini saja, kalau masalah operasi atau penggunaan aplikasinya sebenarnya tidak ada masalah karena apabila kita sudah terbiasa dengan pekerjaan otomatis kita akan paham dengan sendirinya dan juga perusahaan telah mengadakan pelatihan secar berkala mengenai cara menjalankan sistem ini walau awalnya memang sangat sulit saya menerti tapi itu tadi lambat laun kita pasti akan tetap paham mengenai mekanisme dan cara pemprosesan datanya yang di akibatkan oleh faktor kebiasaan user.

2) Pengendalian-Controling (CO)

Berdasarkan hasil wawancara yang saya lakukan kepada pak Ramli selaku user Controling, mengatakan bahwa:

"Kesulitan yang paling utama sebenarnya terletak pada kualitas jarngan dan fasilitas komputer yang di milikinya karena kadang komputer yang di gunakan mengalami gangguan kinerja yang menyebabkan user ini harus meminjam komputer dari user financial karena pada umumnya user CO dan FI merupakan User dengan modul aplikasi yang sama yaitu FICO (Financial and Controling). Akan tetapi jika berbicara mengenai kemudahan dalam menyelesaikan pekerjaan sebenarnya menggunakan sistem ini dapat lebih membantu di bandingkan dengan sebelum penerapan sistem erp ini dan juga operasional perusahaan juga lebih terkontrol karena sudah di sediakan user pengontrol dulukann tidak ada bagian Controling di perusahaan unit, controling lagsung di lakukan oleh SPI".

Lanjut pertanyaan saya mengenai cara kerja sistem ini dan modul apa saja yang berhubungan dengan sistem CO ini, bapak ramli lanjut menjawab "semua modul itu berhubungan dengan sistem CO ini karena modul ini melakukan mengontrolah di semua aspek di dalam perusahan baik itu, biaya, produksi dan gudang sumuanya akan di kontrol di dalam sistem".

3) Produksi -Panel Preparation (PP)

Berdasarkan wawancara yang saya lakukan kepada Bapak saharudin bagian Produksi dan tanaman sebenarnya masalah atau kesulitan yang di alami hanya masalah pada kndisi jaringan komunikasi yang masih buruk sehingga waktu dalam melaporkan informasi terkendala. Tetapi hal ini juga memiliki konpensasi dari kantor direksi yaitu dengan memberikan pemberitahuan mengenai kerlambatan posting di sebabkan oleh apa, jadi harus jelas kendala apa.

Modul ini memiliki hubungan dengan modul financial, material management dan enginering karena dalam modul ini mencatat berapa misalnya berapa besar produksi yang masuk, apa saja yang digunakan dalam memproduksi TBS dan lain sebagainya.

4) Invantory-Material Managent (MM)

Berdasarkan hasill wawancara yang saya lakukan kepada bapak Sainuddin Baso mengungkapkan.

"kalau saya bandingkan kerja saya dengan sebelum penerapan EPR sebenarnya sama saya akan tetapi memang ERP ini memiliki keuanikan tersendiri yaitu dengan proses data yang sangat cepat dan dapat lebih membatu perusahaan, akan tetapi juga memiliki beberapa kendala yaitu kendala pada jaringan, juga misalnya pekerjaan sudah mau di selesaikan akan tetapi tikot dari user PM belum ada karena dalam modul ini dia terintegrasi pada modul PM "Berdasarkan data mengenai modul MM yang saya peroleh dari PT Perkebunan XIV, Peran SAP MM dalam proses bisnis adalah untuk membantu dalam mengelolah kegiatan pada kegiatan pengadaan serta mendukung semua aspek material management (perencanaan, pengendalian dan lain-lain. Untuk melaksanakan 
Jurnal Akuntansi dan Keuangan (JAK)

Volume 6, No. 2 Oktober Tahun 2021

Page: 37 - 49

http://ojs.uho.ac.id/index.php/jak-uho/issue/archive

e-ISSN: 2088-4656

proses bisnisnya, SAP MM akan berinteraksi dengan modul SAP lainya, yaitu: Production planning, Financian and accounting, Enginering dan Controling”.

5) Sumber daya manusia (Human resource (HM)

Berdasarkan data yang saya peroleh dari user HR, HR adalah sebuah sistem yang sangat baik, yang memungkinkan semua informasi yang relevan tentang karyawan dapat ditampilkan dalam hitungan detik. Modul ini menyediakan akses ke semua data SDM dan transaksi dalam satu lokasi. Sehingga dapat menjadi alat untukmengelola peran dan tanggung jawab organisasi, informasi pribadi karyawan, tugas yang berhubungan dengan kehadiran, penggajian, manajemen perjalanan, dan pelatihan karyawan. Hal ini juga membantu dalam menciptakan struktur manajemen perusahaan, dan posisi dalam struktur organisasi.

6) Enginering-precurement management (PM)

Berdasarkan wawancara yang saya lakukan kepada Ny. Sanaria mengungkapkan bahwa: "Pada intinya kesulitan dalam bekerja menggunakan sistem ini adalah pada jaringan komunikasi yang menyebabkan sering terlambatnya saya dalam mengimput data juga masalah fasilitas harusnyakan kami di sedikan fasilitas komputer oleh perusahaan, akan tetapi komputer adalah milik pribadi dan komputer yang sering saya gunakan juga sering eror jadi pekerjaan saya dan pak sainuddin juga bisa terhambat. Tapi kalau di bandingkan dengan sebelum penerapan mungkin kalu dari saya lebih baik yang ini karena pekerjaan saya juga dapat terlaksana dengan baik walaupun kadang kala terkendala sama faktor jaringan komunikasi”.

Modul PM ini dapat berhubungan dengan modul-modul seperti MM, CO karena modul ini berhubungan dengan penggunaan alat alat teknik seperti alat mobil, alat untuk perbaikan jalan produksi dan lain-lain sebagainya.

1) Implemtasi ERP Dalam Meningkatkan Kinerja SPI

a. Tugas Dan Fungsi Auditor Internal

Implementasi Enterprise Resource Planning tidak berpengaruh signifikan terhadap mempermudah auditor dalam menyelesaikan tugas dan fungsinya hal ini di perjelas oleh staf audit komersil (Keuangan, Tanaman, produksi, Pengadaan barang/jasa, enginering) PT Perkebunan XIV, Ibu nurafizah divia maharani S,Ak:

"Implementasi Enteprise Resource Planning tidak memliki dampak yang baik untuk kemudahaan auditor dalam melakukan pengauditan, alasannya yaitu

1. Pelatihan Enterprise Resource planning untuk auditor belum berjalan optimal, hanya beberapa personil yang paham dalam menggunakan Tcode SAP

2. Akun auditor untuk mengakses Enterprise Resource Planning Hanya Satu

3. Ada beberapa informasi yang di butuhkan tidak tercantum dalam Enterprise Resource Planning.

Tidak perbedaan sebelum dan sesudah penerapan enterprise resource planning yang di rasakan oleh auditor internal dalam melakukan audit, hal ini di pertegas dengan pernyataan staf audit komersil PT Perkebunan XIV, ibu nurafizah divia maharani S.Ak yaitu:"pada dasarnya sistem pembukuan dan pelaporan keuangan ptpN XIV sebelum penerapan Enterprise Resource Planning di lakukan melalui TUK 20. Informsi di dalamnya lengkap dan terperinci, sejak pengimplementasian Enterprise Resource planning SAP unit objek auditor tetap menggunakan TUK 20 untuk melakukan pengontrolan kas. Oleh karena itu tidak ada perbedaan bagi kmi dalam melakukan audit sebelum maupun sesudah pengimplementasian". 
Jurnal Akuntansi dan Keuangan (JAK)

Volume 6, No. 2 Oktober Tahun 2021

Page: 37 - 49

http://ojs.uho.ac.id/index.php/jak-uho/issue/archive

e-ISSN: 2088-4656

2) Pelaksanaan Audit

Implementasi Enterprise resource Planning tidak berdampak secara signifikan dalam kulaitas audit hal ini di perkuat denga pernyataan ibu nurafizah divia maharani S.Ak yaitu:

"Dengan adanya beberapa informasi rinci yang tidak ada di Enterprise Resource Planning SAP, oleh karena itu dampek setelah di terapkannya sistem ERP tidak berdampak signifikan terhadap kalitas audit, dampak dari penerapan ERP SAP hanya pada kecepatan dalam memperoleh informasi data.

Berdasarkan hasil wawancara mengenai kuantitas atau banyaknya pekerjaan yang dapat di selesakan auditor setelah penerapan sistem ini tidak berpengaruh sama sekali terhadap penyelesaian pemeriksaan audit.

Waktu yang di butuh kan audir pada dasarnya sama seperti sebelum penerapan sistem Enterprise Resouce Planning hal inidi perkuat dengan penyataan ibu Nurafizah Divia Maharani S.Ak yang mengatakan: "Waktu yang di butuhkan sama seperti sebelum penerapan sistem Enterprise resource planning karena kami tetap harus melakukan pemeriksaan fisik di lapangan. SAP hanya memuat informasi biaya dan tidak menggambarkan fisik di kebun'. Kesuliitan auditor internal PT Perkebunn XIV hanya terletak pada Akses tcode yang cukup rumit hal ini di karenakan kurangnya pelatihan yang di berika kepada auditor dalam memahami sistem Enterprise Resource Planning tersebut.

3) Enterprise Resource Planning Bagi Kinerja Perusahaan

Dengan data yang terintegrasi secara langsung oleh stekholder dalam perusahaan tentunya dapat memberikan dapmpak fositf bagi perusahaan dalam memonitoring biaya, produksi dan komponen dalam laporan keuangan hal ini di perkuat dengan penyataan staf audit komersil PT Perkebunan XIV yaitu:

"Sebagai perusahaan holding perkebunan, sistem ERP SAP akan lebih mempermudah holding untuk memonitoring biaya, produksi serta komponen-komponen laporan keuangan lainnya".

\section{Pembahasan}

Berdasarkan hasil wawancara yang di lakukan mengenai inplementasi Enterprise Resource Planning yang di lakukan oleh 6 User (Pengguna) dengan melihat kondisi penenerapan sistem yang masih menjadi masalah utama yaitu dengan kualias jaringan komunikasi yang ada di lingkup kantor Unit kebun Asera sehingga dapat menghambat dalam melakukan pengimputan transaksi ke holding dan juga dapat menghambat kerja dari setiap karyawan. Akan tetapi dari masalah tersebut dapat di atasi dengan kesadaran masing-masing karyawan untuk mencari loksi yang memiliki koneksi internet yang lebih stabil dalam menyelesaikan pekerjaan dalam pengimputan data SAP.

Berdasarkan hasil analisis mengenai implementasi Enterprise Resource Planning SAP dalam meningkatkan kinerja auditor internal di PT Perkebunan XIV dengan memberikan wawanacara kepada pihak auditor terkait dampak yang di hasilkan sistem Enterprise resource Planning dalam meningkatkan kinerja auditor internal dengan hasil tersebut peneliti memperoleh bahwa kemampun Enterprise resource planning dalam meningkatkan kinerja satuan pengawasan internal (auditor internal) dalam melaksanakan tugas, fungsi dan tanggung jawabnya sebagai pemeriksa internal perusahaan masih belum memiliki dampak yang cukup baik hal ini di sebabkan oleh beberapa faktor yaitu (Ibu Nurafizah divia Maharani): 
Jurnal Akuntansi dan Keuangan (JAK)

Volume 6, No. 2 Oktober Tahun 2021

Page: 37 - 49

http://ojs.uho.ac.id/index.php/jak-uho/issue/archive

e-ISSN: 2088-4656

1. Pelatihan Enterprise Resource planning untuk auditor belum berjalan optimal, hanya beberapa personil yang paham dalam menggunakan Tcode SAP.

2. Rumitnya tcode dalam sistem Enterprise Resource Planning SAP.

3. Akun auditor untuk mengakses Enterprise Resource Planning Hanya Satu

4. Ada beberapa informasi yang di butuhkan tidak tercantum dalam Enterprise Resource Planning.

Audit adalah pengumpulan dan evaluasi bukti tentang informasi untuk mementukan dan melaporakn terkait dengan tingkat kesesuaian suatu informasi dengan kriteria yang telah di tetapkan. Audit ini tentunya harus di lakukan oleh orang yang mempunyai kompetensi dan pemahaman dalam audit (Arens et al, 2014). Dengan di implementsikannya sistem ERP diharapkan dapat memudahkan pekerjaan auditor berbantuan IT. Bahkan apabila di optimalkan dapat mendukung pelaksanaan tugas auditor dalam mendeteksi kecurangan (fraud). Tekhnik auditor dalam mencapai tujuan pemeriksaan yang mengacu pada prosedur dan pada prosedur pemeriksaan (audit) yang mengkhususkan untuk pengujian data-data dan perangkat lunak.

Penggunaan tekhnik audit berbantuan komputer antara lain telah di atur dalam standar profesional akuntan publik (IAPI, 2011, PSA No. 55 tentang tekhnik audit berbantuan komputer. Dalam standar ini di jelaskan mengenai tipe dan manfaatnya, manfaat tekhnik audit berbasis komputer (IAPI, 2011) adalah.

1. Pengujian rincian transaksi dan saldo-seperti, penggunaan perangkat lunak audit untuk menguji semua (suatu sampel) transaksi dalam file komputer;

2. Prosedur review analitik-seperti, penggunaan perangkat lunak audit untuk mengidentifikasi unsur atau fluktuasi yang tidak biasa;

3. Pengujian pengendalian (test of control) atas pengendalian umum sistem informasi komputer-seperti, penggunaan data uji untuk menguji prosedur akses ke perpustakaan program (program libraries);

4. Pengujian pengendalian atas pengendalian aplikasi sistem informasi komputer seperti, penggunaan data uji untuk menguji berfungsinya prosedur yang telah diprogram;

5. Mengakses file, yaitu kemampuan untuk membaca file yang berbeda record-nya dan berbeda formatnya;

6. Mengelompokkan data berdasarkan kriteria tertentu;

7. Mengorganisasi file, seperti menyortasi dan menggabungkan;

8. Membuat laporan, mengedit dan memformat keluaran;

9. Membuat persamaan dengan operasi rasional logika

Dalam menggunakan sistem informasi dalam melakukan prosedur juga memiliki beberapa pertimbangan yang harus di pertimbangkan yang harus di lakukukan dalam melakukan pemeriksaan antara lain:

1) Pengetahuan, keahlian, dan pengalaman yang di miliki oleh auditor.

2) Tersedianyan proses bisnis entitas auditi berbasis komputer

3) Ketidak pastian apabila di lakukan pengujian manual

4) Efektifitas dan efesiensi waktu

5) Kendala pelaksanaan.

Sesuai SA seksi 335 (PSA No.57) tentang Auditing dalam Lingkungan Sistem Informasi Komputer, pada paragraf 04 sampai dengan paragraf 06 menjelaskan tingkat keterampilan dan kompetensi auditor yang harus dimiliki bila melaksanakan suatu audit dalam lingkungan sistem informasi komputer dan memberikan panduan bila mendelegasikan 
Jurnal Akuntansi dan Keuangan (JAK)

Volume 6, No. 2 Oktober Tahun 2021

Page: 37 - 49

http://ojs.uho.ac.id/index.php/jak-uho/issue/archive

e-ISSN: 2088-4656

pekerjaan kepada asisten dengan keterampilan sistem informasi komputer atau bila menggunakan pekerjaan yang dilaksanakan oleh auditor independen lain atau tenaga ahli yang memiliki keahlian di bidang sistem informasi komputer Secara khusus, auditor harus memiliki pengetahuan memadai untuk merencanakan, melaksanakan, dan menggunakan hasil penggunaan TABK. Tingkat pengetahuan yang harus dimiliki oleh auditor tergantung atas kompleksitas dan sifat TABK dan sistem akuntansi entitas.

\section{Kesimpulan}

\section{Kesimpulan, Keterbatasan, Implikasi dan Rekomendasi}

Berdasakan anlisis data yang telah di lakukan oleh peneliti yaitu mengenai analisis implementasi enterprise resource planning dalam meningkatkan kinerja satuan pengawasan internal di PT Perkebunan XIV maka dapat di ambil kesimpulan sebagai berikut:

1. Implementasi Enterprise Resource Planning belum efektif digunakan auditor dalam menyelesaikan tugas dan fungsinya Hal ini sebabkan oleh kurangnya pemahaman auditor internal dalam menggunakan sistem Enterprise Resource Planning di lingkup satuan kerja pengawasan internal PT perkebunan XIV serta data yang di hasilkan oleh ERP SAP belum terinci.

2. Penarapan sistem ERP SAP memberikan dampak yang sangat baik dalam memonitoring kegiatan perusahaan di karenakan sistemnya yang sudah terintegrasi langsung ke Direksi Holding PT Perkebunan Nusantara.

3. Implementasi Enterprise resource Planning tidak berdampak secara signifikan dalam kulaitas Pemeriksaan audit, hal ini di sebabkan karena ada beberapa data yang tidak tersedia dalam program ERP SAP, oleh karena itu Penerapan sistem ERP belum memiliki berdampak yang begitu baik terhadap kalitas audit, dampak dari penerapan ERP SAP hanya pada kecepatan dalam memperoleh informasi data.

\section{Implikasi}

Berdasarkan hasil penelitian tersebut imlokasi bagi penelitian ini adalah meningkatkan kinerja sistem informasi dan sarana prasarana dalam menunjang keberhasilan atas penerapan sistem, serta memberikan pelatihan mengenai sistem informasi terhadap auditor internal dan juga karyawan pengguna sistem ini.

\section{Keterbatasan}

Berdasarkan pembahasan pada bagian sebelumnya, dapat disimpulkan beberapa keterbatasan dalam penelitian ini sekaligus menjadi saran bagi pelaksanaan penelitian berikutnya sebagai berikut:

1. Penelitian ini hanya meneliti pengaruh variabel ekspektasi kinerja, ekspektasi usaha, pengaruh sosial, dan kondisi-kondisi Pemfasilitasan ke niat keperilakuan dan perilaku menggunakan. Penelitian ini belum menghubungkan ke hasil-hasil pemakaian karena penggunaan sistem ERP secara single system pada perusahaan ini baru dimulai. Hal ini masih perlu dikembangkan.

2. Sebagian besar responden yang mengisi kuesioner adalah krani yang bekerja di kantor kebun di mana krani memiliki latar belakang pendidikan terakhir jenjang SLTA. Meskipun sebenarnya krani memiliki kemampuan dalam menggunakan sistem ERP, namun level krani memiliki kelemahan kurangnya pemahaman tentang sistem ERP secara mendalam, sehingga akan lebih baik jika responden seimbang yang berasal dari pejabat dan staf. 
Jurnal Akuntansi dan Keuangan (JAK)

Volume 6, No. 2 Oktober Tahun 2021

Page: 37 - 49

http://ojs.uho.ac.id/index.php/jak-uho/issue/archive

e-ISSN: 2088-4656

\section{Rekomendasi}

Adapun saran yang dapat penulis berikan yaitu:

1. Bagi corporate (Perusahaan)

PT Perkebunan XIV sebaiknya memberikan fasilitas berupa alat komputer dan juga meningkatkan kualitas koneksi internet yang stabil di lingkup kantor dalam meminimalisir terjadinya eror pada pengimputan data yang di lakukan oleh setiap User ERP SAP. PT perkebunan XIV juga harus memberikan serta memaksimalkan pelatihan sistem Enterprise Resource Planning bagi setiap auditor dalam penggunaan sistem ini serta menambah beberapa akun ERP SAP untuk memaksimalkan kerja Satuan pengawasan intern.

2. Bagi Peneliti Selanjutnya

Penelitian selanjutnya di saran kan untuk melakukan pengujian pengaruh sistem Enterprise Resource Planning terhadap kinerja auditor internal untuk melihat seberapa jauh pengaruh sistem terhadap kinerja auditor internal dengan menggunakan indikator kualitas, kuantitas, ketepatan waktu serta komunikasi.

\section{DAFTAR PUSTAKA}

Ahmad, S Ruky. 2002. Sistem Manajemen Kinerja. Jakarta: PT Gramedia Pustaka Utama.

Arens, A.A, Elder, R.J., dan Beasley, M.S. 2014. "Auditing and Assurance Services An Integrated Approach (15th ed.)". London: Pearson Education. Diakses di https://itjen.dephub.go.id/2019/03/23/antara-audit-dengan-teknologi-informasi-saat-ini/

Asian Development Bank. 2017. Asean Corporate Governance Scorecard Country Reports and Assessments 2015. In Asian Development Bank.

Asian Development Bank. 2017. Asean Corporate Governance Scorecard Country Reports and Assessments 2015. In Asian Development Bank

Bidgoli, Hossein. 2004. Ensiklopedia Internet, Volume 1, John Wiley \& Sons, Inc hal. 707. Diakses 24 september 2020

Boyntosn, C William, Raymond N. Johnson, Walter G. Kell. 2007. Modern Auditing, Jakarta: Erlangga.

http;//learn-informationsystem.blogspot.com/2016/12advantages-using-sap-systemaplication.html

https://jeannerroselia.wordpress.com/2013/07/18konsep-dasar-erp/.diakses september 2020) Mulyadi. 2008. Sistem Akuntansi. Jakarta: Salemba Empat.

O’Brien, James A. 2005. Pengantar Sistem Informasi Akuntansi: Perspektif Bisnis dan Manajerial, Terjemahan. 12th edition. Jakarta: Salemba Empat.

Peraturan Menteri Negara BUMN Nomor: PER-01/MBU/2012 tentang Penerapan Tata Kelola Perusahaan

Peraturan Menteri Negara BUMN Nomor: Per-01/MBU/2011 tentang Penerapan tata Kelola Perusahaan yang baik (Good Corporate Governance) pada BUMN

Sabana, A. 2002. Enterprise Resources Planning di PT Ultrajaya Milk Industry \& Trading Tbk. Warta Ekonomi.

Saharia, A., Koch B., \& Tucker R. 2008. ERP system and internal audit. Journal of information systems. Vol.9 No.2.

Standar Profesional Akuntan Publik (IAPI, 2011), PSA No. 59 (SA Seksi 327) 
Jurnal Akuntansi dan Keuangan (JAK)

Volume 6, No. 2 Oktober Tahun 2021

Page: 37 - 49

http://ojs.uho.ac.id/index.php/jak-uho/issue/archive

e-ISSN: 2088-4656

Sugiyono. 2017. Metode Penelitian Kuantitatif dan Kualitatif R\&D. Bandung: Alfabeta 